\title{
ПРАВОВАЯ ПРИРОДА МОРСКОЙ БЛОКАДЫ И МЕЖДУНАРОДНОЕ ПРАВО
}

\author{
Костыря Е. В., Иванова А. В.
}

\section{ВВЕДЕНИЕ}

В соответствии с одним из основных принципов современного международного права, закрепленных в Уставе ООН, в отношениях между государствами запрещается применение силы и угрозы силой. Морская блокада, являющаяся одним из видов применения силы, может быть правомерной только в том случае, если ее необходимость вытекает из самообороны как средства борьбы с агрессией и из решения совета Безопасности ООН, который в силу ст. 42 Устава ООН сочтет эту меру необходимой для поддержания или восстановления международного мира и безопасности.

Морская блокада - система мер, предпринимаемых во время вооруженного конфликта с целью прекращения доступа к морскому побережью противника, чтобы вынудить его отказаться от использования собственных или оккупированных им портов, военно-морских баз, побережья и примыкающих к ним морских вод для торговых и иных связей морем с другими государствами. Воюющие государства, объявляя морскую блокаду, стремятся прервать морские коммуникации неприятельского государства, чтобы максимально ослабить его экономические ресурсы и лишить его возможности торговли с нейтральными странами.

\section{1. Исторический аспект становления морской блокады}

Морская блокада как форма вооруженной борьбы зародилась вместе с возникновением войн на море. Направленная на изоляцию отдельных приморских городов и прибрежных районов, она применялась уже гребным флотом в войнах древнего мира. Тогда блокадные действия велись только в прибрежных водах, охватывали ограниченные участки побережья и выражались в уничтожении неприятельских судов и разграблении прибрежного населения. Но уже в те времена основной направленностью таких действий было стремление прекратить морские сообщения противника, изолировать его от внешнего мира, истощить экономику и принудить принять требования победителя. С тех пор морская блокада в той или иной степени становится постоянной составной частью почти всех войн на море, превращаясь иногда даже в основное их содержание. 
Исторический аспект становления морской блокады связан с его гнесеологией. Он проявляется в том, что предпосылкой его возникновения были, например, интересы государств, направленные на создание собственной изоляции с моря в случае военного положения. Необходимо отметить, что в процессе развития масштабов военных действий, а также материальной базы вооруженной борьбы на море интересы государств и соответственно условия морской блокады несколько видоизменялись или вообще имели совершенно иные, актуальные для определенных государств (их географического положения, военного потенциала, временного промежутка военных действий) условия, но естественное стремление государств к материальной защищенности и желание быть уверенным в будущем оставались на протяжении многих времен.

Экономический аспект институциализации морской блокады состоит в том, что морская блокада основывается на предварительном создании военных запасов (фондов) с целью изоляции с моря отдельных приморских городов либо районов побережья государства.

По мере развития материальной базы вооруженной борьбы на море, а также повышения значения экономических связей между государствами и морских перевозок как важнейшего средства их осуществления роль морской блокады в войнах непрерывно повышалась, возрастал и ее размах. К решению блокадных задач все в больших масштабах привлекались самые разнообразные силы и средства; формы их действий усложнялись. Морская блокада постепенно превращалась в целую систему насильственных мероприятий, направленных на изоляцию с моря вначале отдельных приморских городов, потом районов побережья, а затем и целых государств и даже коалиций.

Первой морской блокадой называют блокаду, которую проводили голландцы в 1584 г. против испанцев, оккупировавших Фландрию. В 1630 г. была опубликована декларация Генеральных Штатов Голландии, которая применила принципы осады в сухопутных условиях к «осаде с моря», т. е. к морской блокаде. В Уайтхоллском договоре 1689 г. Англия и Голландия требовали от многих государств запрета своим подданным торговать с Францией. В договоре указывалось, что все нейтральные суда, идущие во французские порты, будут принуждены изменить курс. Если же они будут проходить после нотификации, то будут захвачены в качестве приза ${ }^{1}$. До этого в 1652 г. голландцы объявили по существу декларативную блокаду

\footnotetext{
1 Колодкин А.Л. Морская блокада и современное международное право. Советское государство и право. 1963. № 4. С. 94. 
всех Британских островов. Такой же «бумажной», неэффективной блокадой считается блокада Наполеоном Англии, декларированная берлинским и миланским декретами. Типичная «бумажная» блокада была установлена союзниками против рижского порта во время Крымской войны, когда один военный корабль находился в 120 милях от судоходного канала в Лисер Орт. Неэффективной была и морская блокада, объявленная в 1877 г. Турцией против русских портов.

Декларативные блокады формально давали право объявившим их государствам рыскать по огромным просторам, нарушать морскую торговлю и захватывать нейтральные суда в неопределенных границах от открытого моря, хотя они не имели реальных сил в действительности блокировать какой-либо порт или район. Естественно, это вызвало законное недовольство многих нейтральных стран и послужило основанием для требования запретить неэффективную блокаду. Впервые такой шаг сделала Россия, когда 28 февраля 1856 г. это было подтверждено Парижской декларацией о морской войне.

В зависимости от задач и масштабов блокадных действий, состава участвовавших сил, а также от важности блокируемых объектов морская блокада, которая сначала имела лишь тактическое значение, в процессе развития постепенно становилась фактором оперативного и даже стратегического характера.

В ходе многовекового процесса превращения военного флота из гребного в парусный, вооружения морских кораблей все более совершенной артиллерией, особенно с появлением регулярного флота (примерно XVII в.), роль морской блокады непрерывно возрастает, повышается ее эффективность, расширяются блокадные зоны.

В этот период морская блокада применялась не только в целях пресечения доставки морем в блокированную зону всех видов грузов, но и для воспрещения выхода из баз военно-морских сил противника.

Следовательно, методами морской блокады часто решались две задачи, каждая из которых вела к достижению единой цели - изоляции врага от внешнего мира. Первая из них состояла в перерыве внешних морских коммуникаций блокируемого, вторая - в воспрещении выхода вражеского военного флота в открытое море для осуществления своих задач, в т. ч. и для обеспечения морских сообщений.

В этой связи представляют определенный интерес действия морских сил в русско-японской войне (1904-1905 гг.) ${ }^{2}$.

2 Лоченко Н.П., Шлома В.И. Морская блокада как форма вооруженной борьбы. Морской сборник / гл. ред. Г.И. Щедрин. Москва : Издательство «Красная звезда», 1971. № 2. С. 43. 
Следует отметить, что, например, японское командование для того, чтобы обеспечить перевозки своих войск на Ляодунский полуостров, а затем и прикрытие их флангов с моря, решило с апреля 1904 г. блокировать русскую эскадру в Порт-Артуре. Для осуществления этой задачи японцы производили систематические минные постановки и привлекали значительные силы своего флота ${ }^{3}$.

В процессе определения международного значения морской блокады в своем исследовании Н.П. Лоченко и В.И. Шлома приходят к выводу, что в Первую мировую войну (1914-1918 гг.) морская блокада, предпринятая западными государствами (Германией, Англией), несмотря на ее широкие масштабы, не привела ни одну из воевавших сторон к победе. Она создавала только необходимые для этого предпосылки. Например, Германия из-за блокады почти полностью лишилась подвоза извне сырья и продовольствия, что повлияло на сроки окончания войны и качество вооружения ее армии, позволило странам Антанты достичь значительного военного преимущества. Подводная блокада Англии потрясла ее экономику, поставила на грань катастрофы, но, не подкрепленная активными боевыми действиями, направленными на разгром вооруженных сил, не вывела ее из войны.

По-иному к организации блокады черноморских проливов (1916-1917 гг.) подошли в русском флоте. Систематическими скрытными минными постановками на походах к проливу Босфор в сочетании с активными действиями подводных лодок и надводных сил, включая линкоры, здесь удалось добиться воспрещения входа в Черное море крупных неприятельских кораблей и полного нарушения турецких морских коммуникаций в этом море, а также сорвать перевозки Турцией своего угля и нефти из Румынии в юго-западные части Черного моря.

Во Второй мировой войне (1939-1945 гг.) для согласования всех мероприятий, устремленных на осуществление блокады, создается даже соответствующий аппарат: во Франции - министерство блокады, а в Англии - министерство экономической войны. Затем организуется специальный комитет, призванный координировать усилия обеих стран, направленные на ведение блокады противника. В свою очередь Германия объявила в 1940 г. полную блокаду Англии. Все суда, шедшие к ее берегам или берегам ее владений, подвергались опасности потопления подводными лодками, надводными кораблями и авиацией․․ Так,

\footnotetext{
3 Лоченко Н.П., Шлома В.И. Морская блокада как форма вооруженной борьбы. Морской сборник / гл. ред. Г.И. Щедрин. Москва : Издательство «Красная звезда», 1971. № 2. С. 43.

4 Там же. С. 45. 
морская блокада в ходе Второй мировой войны перерастает в экономическую войну, распространившуюся практически на весь Мировой океан.

Подводя итог, можно утверждать, что морская блокада, хоть и является мощным средством давления на экономику противника, но, не подкрепленная активными наступательными действиями, преследующими разгром главных группировок его вооруженных сил, непосредственно к достижению целей войны не приводит. Подтверждению этому служит опыт двух мировых войн, в которых, вопреки ожиданиям, даже использование для блокады новых сил и средств борьбы без разгрома основных группировок врага полной победой не завершалось.

\section{2. Морская блокада и международное право}

Под морской блокадой современное международное право понимает преграждение военно-морскими силами воюющих государств доступа с моря к берегам, находящимся во власти или под контролем противника либо содействующего ему невоюющего государства.

Н.П. Лоченко, раскрывая понятие морской блокады, утверждает, что «морская блокада как одна из форм вооруженной борьбы применяется воюющими государствами для преграждения доступа морем к берегу, портам и военно-морским базам, находящимся под контролем противника ${ }^{5}$. В Морском энциклопедическом справочнике под редакцией Н.Н. Исанина понятие «морская блокада» определено как «одно из средств ведения морской войны, заключающееся в преграждении военно-морскими силами одного из воюющих государств доступа с моря к побережью, принадлежащему другому либо контролируемого им, с целью прервать морское сообщение и дезорганизовать морскую торговлю» ${ }^{6}$. Морская блокада, одно из средств ведения морской войны, также раскрывается в морском энциклопедическом словаре В.Ф. Сидорченко. Также определено, что «блокада может распространяться на побережье или на всю страну и в этом случае - на открытое море или даже нейтральные страны» ${ }^{7}$. В военно-морском словаре под редакцией В.Н. Чернавина морская блокада определяется как «изоляция побережья, островов (прибрежного) государства, отдельных его участков, военно-морских баз, проливов, зон путем

\footnotetext{
5 Лоченко Н.П., Шлома В.И. Морская блокада как форма вооруженной борьбы. Морской сборник / гл. ред. Г.И. Щедрин. Москва : Издательство «Красная звезда», 1971. № 2. С. 41.

6 Морской энциклопедический справочник : в 2 т. Т. 1 / под ред. Н.Н. Исанина. Ленинград : Судостроение, 1986. С. 456.

7 Морской энциклопедический словарь : в 3 т. Т. 2 / под ред. В.В. Дмитриева. СанктПетербург : Судостроение, 1993. С. 307.
} 
пересечения внешних связей через море и воспрещение прохода сил флота противника через блокадную зону. Для осуществления морской блокады привлекаются надводные корабли и авиация, широко применяется минное оружие» ${ }^{8}$.

Цель морской блокады - ослабление экономических ресурсов неприятельского государства и лишение его возможности усиливать свою военную мощь путем торговли с нейтральными странами. Воюющие государства, объявляя морскую блокаду, стремятся прервать морские коммуникации неприятельского государства, чтобы максимально ослабить экономические ресурсы противной стороны и лишить её возможности торговли с нейтральными странами. Преднамеренное нарушение блокады кем бы то ни было влечет за собой конфискацию судна и груза. Именно в этом плане - главным образом в связи с состоянием войны и с действиями воюющих - упоминается о морской блокаде и в международно-правовой литературе.

Морская блокада затрагивает интересы и невоюющих государств, поскольку препятствует поддержанию сообщений с блокируемым районом и всякие попытки судов проникнуть туда могут закончиться захватом их блокирующей державой. Таким образом, в связи с тем, что от блокады страдают не только воюющие государства, но и нейтральные, ее объявление и проведение регламентируются соответствующими нормами международного права.

Морская блокада регламентируется правилами Парижского мирного договора 1856 г. и Лондонской декларацией о праве морской войны 1909 г. Но нельзя не указать международные соглашения, которые содержат важные требования для обеспечения гарантий эксплуатации торговых судов, мирных мореплавателей, госпитальных судов, перевозящих больных и раненых в условиях морской блокады. Основной смысл и цель международных соглашений - ограничить войну боевыми действиями лишь между вооруженными силами враждующих государств и уберечь, насколько возможно, гражданское население от влияния войны. В Лондонской декларации о праве морской войны 1909 г. рассматривается тенденция избавлять гражданское население от ужасов войны.

Так, согласно нормам Парижского мирного договора 1856 г. (акт подписан на конгрессе Англией, Австрией, Пруссией, Россией, Сардинией (ныне Италия) и Турцией) установлены новые четыре принципа международного морского права:

8 Военно-морской словарь / гл. ред. В.Н. Чернавин. Москва : Воениздат, 1989. С. 50. 
1. Блокада может быть объявлена лишь в случае наличия у блокирующего достаточного числа военных судов для воспрепятствования морскому доступу к блокируемому берегу.

2. Неприятельский груз, за исключением военной контрабанды, не подлежит захвату на нейтральном судне.

3. Равным образом нейтральный груз на неприятельском судне не подлежит захвату, отменено каперство .

К парижскому мирному договору 1856 г. в дальнейшем присоединились Швеция и Норвегия, Дания, Нидерланды и Португалия. Испания и Соединенные Штаты Америки отказались присоединяться, но в ходе военных действий в войне за Кубу соблюдали эти четыре пункта.

Международные правила морской блокады зафиксированы и в Главе I Лондонской декларации о праве морской войны 1909 г., так, согласно ст. 1 «блокада может быть применима лишь к портам и берегам, принадлежащим неприятелю или им занятым» ${ }^{10}$.

Морская блокада не распространяется на международные каналы и проливы. Морская блокада должна быть «эффективной, т. е. реальной и осуществляться путем действительного блокирования определенного района военно-морской эскадрой, иначе она будет «бумажной», фиктивной, что давало в прошлом некоторым странам основания для задержания в открытом море нейтральных судов, идущих к якобы заблокированным берегам, и конфисковывать их груз» ${ }^{11}$.

В соответствии с Парижским мирным договором 1856 г. блокада, чтобы быть обязательной, должна быть действенной, то есть поддерживаться силой, достаточной для фактического воспрепятствования доступа к неприятельскому побережью ${ }^{12}$. Несоблюдение перечисленных условий делает морскую блокаду недействительной. В соответствии с Лондонской декларацией о праве морской войны 1909 г. вопрос о действительности блокады есть вопрос факта (ст. 3), блокада не считается снятою, если блокирующие силы временно удалятся вследствие непогоды при объявлении морской блокады ${ }^{13}$.

\footnotetext{
9 Парижский мирный договор 1856 г. URL: https://ru.wikisource.org/.

10 Лондонская декларация о праве морской войны 1909 г. URL: http://docs.cntd.ru/ document/902038151/

11 Морской энциклопедический справочник : в 2 т. Т. 1 / под ред. Н.Н. Исанина. Ленинград : Судостроение, 1986. С. 456.

12 Парижский мирный договор 1856 г. URL: https://ru.wikisource.org/.

13 Лондонская декларация о праве морской войны 1909 г. URL: http://docs.cntd.ru/ document/902038151.
} 
Блокада, чтобы быть обязательной, должна быть объявлена или оповещена (ст. 8) ${ }^{14}$. Так, согласно ст. 9 Лондонской декларации о праве морской войны 1909 г. начало морской блокады объявляется или блокирующим государством, или же действующими от ее имени морскими властями. Объявление о блокаде определяет день начала блокады, географические границы блокируемого побережья, а также срок, который предоставляется нейтральным судам для выхода.

Объявление о блокаде, ее расширения в своих пределах, а также возобновления после ее снятия оповещается как нейтральным государствам государством блокирующим посредством сообщения, обращенного к самим правительствам и к аккредитованным при нем их представителям, так и к местным властям начальником блокирующей силы. Власти же эти со своей стороны известят о блокаде военных консулов, исполняющих обязанности в порту или на побережье, подвергающихся блокаде (ст. 11) ${ }^{15}$. Также согласно этой статье осуществляется добровольное снятие блокады и всякое сокращение ее действия.

\section{3. Обеспечение безопасности мирного судоходства}

Основным спорным вопросом при введении морской блокады всегда был вопрос о проходе судов третьих стран. Лондонская декларация о праве морской войны 1909 г. содержит положения, которые регламентируют действия нейтральных судов во время морской блокады. Так, в соответствии со ст. 16, если судно, приближающееся к блокированному порту, не знало о существовании блокады или нельзя предполагать, что оно не знало, то оповещение должно быть сделано самому судну непосредственно через офицера одного из судов блокирующей силы. Это оповещение должно быть занесено в судовой журнал с указанием дня и часа и географического положения судна в данный момент. В случае бедствия, удостоверенного какою-нибудь властью блокирующих сил, согласно ст. 7 нейтральное судно может войти в блокируемую местность и затем из нее выйти под условием не оставлять и не брать там никакого груза. Условия морской блокады должны применяться беспристрастно к судам под различным флагом ${ }^{16}$. Захват нейтральных судов за нарушение блокады может быть осуществлен лишь в районе действия военных судов, на которые возложено обеспечение действительности блокады (ст. 17) ${ }^{17}$.

\footnotetext{
14 Лондонская декларация о праве морской войны 1909 г. URL: http://docs.cntd.ru/ document/902038151.

15 Там же.

16 Там же.

17 Там же.
} 
Конвенция о некоторых ограничениях в пользовании правом захвата в морской войне 1907 г., которая призвана обеспечивать справедливое применение права в морских международных отношениях в военное время, закрепляет в форме общих правил свод гарантий, присвоенных мирной торговле и безвредному труду, предусматривает абсолютную неприкосновенность госпитальных судов, перевозящих больных и раненых и отмеченных определенной эмблемой, а также судов, выполняющих научные, религиозные функции, и судов, перевозящих парламентеров. А также правил ведения военных действий на море. Так, согласно правилам данной конвенции почтовая корреспонденция нейтральных или воюющих, будь то официальная или частная, найденная в открытом море на нейтральном или неприятельском судне, неприкосновенна, в случае захвата судна она досылается захватчиком с наименьшим по возможности опозданием. Исключение допускается в случае нарушения блокады, если корреспонденция направлена в блокируемый порт или отправляется оттуда.

Суда, исключительно предназначенные для берегового рыболовства или для потребностей мелкого местного мореплавания, не подлежат захвату, как равно и их машины, снасти, приспособления и груз. Эта льгота перестает к ним применяться, как только они принимают какое-либо участие в военных действиях. Равным образом освобождены от захвата суда, выполняющие научные, религиозные и филантропические поручения.

Когда неприятельское торговое судно захвачено воюющими, его экипаж и подданные нейтральной Державы не подвергаются военному плену ${ }^{18}$. Также согласно Парижскому мирному договору 1956 г. неприятельский груз не может быть захвачен, если он находится на нейтральном судне (за исключением военной контрабанды), а груз нейтрального государства не может быть предметом захвата (за исключением военной контрабанды), даже если он транспортируется неприятельским судном.

В процессе определения международного значения культурных ценностей, констатируя, что культурным ценностям был нанесен серьезный ущерб в ходе последних вооруженных конфликтов и что вследствие развития военной техники они все больше подвергаются угрозе разрушения, и так как культурные ценности являются культурным наследием для всего человечества, поскольку каждый народ

18 Конвенция о некоторых ограничениях в пользовании правом захвата в морской войне 1907 г. URL: http://hrlibrary.umn.edu/instree/R1907j.html. 
вносит свой вклад в мировую культуру, а также, руководствуясь принципами защиты культурных ценностей в случае вооруженного конфликта, установленных в Гаагских конвенциях 1899 г. и 1907 г. и в Вашингтонском Пакте от 15 апреля 1935 г., была принята Гаагская конвенция о защите культурных ценностей в случае вооруженного конфликта в 1954 г. Данная Конвенция закрепляет в форме общих правил свод гарантий относительно специальной защиты культурных ценностей всех народов. Так, согласно ст. 8 под специальную защиту может быть взято ограниченное число укрытий, предназначенных для сохранения движимых культурных ценностей в случае вооруженного конфликта, центров сосредоточения культурных ценностей и других недвижимых культурных ценностей, имеющих очень большое значение, и они не используются в военных целях ${ }^{19}$.

Транспорт, используемый исключительно для перевозки культурных ценностей, для перевозки на другую территорию может быть взят под специальную защиту, находиться под международным контролем, предусмотренным Исполнительным Регламентом, и обозначаться отличительным знаком, а Высокие Договаривающиеся Стороны Конвенции обязаны воздерживаться от любого враждебного акта в отношении транспорта, находящегося под специальной защитой (ст. 12). Отличительный знак Конвенции предусматривает собой щит, заостренный снизу, разделенный на четыре части синего и белого цвета (щит состоит из квадрата синего цвета, один из углов которого вписан в заостренную часть щита, и синего треугольника над квадратом; квадрат и треугольник разграничиваются с обеих сторон треугольниками белого цвета) (ст. 16) ${ }^{20}$. Кроме того, Гаагская конвенция 1954 г. предусматривает иммунитет от конфискации или взятия в качестве приза или захвата культурных ценностей и транспортных средств, занятых исключительно перевозкой этих ценностей. В качестве приза могут выступать неприятельские торговые суда и грузы, находящиеся в государственной или частной собственности, захваченные в войне на море, а также нейтральная собственность, если она является военной контрабандой (ст. 14) ${ }^{21}$.

Во время военной блокады международное право не запрещает использование минного оружия. Так, в 1907 г. была принята Гаагская

19 Гаагская конвенция о защите культурных ценностей в случае вооруженного конфликта 1954 г. URL: https://www.icrc.org/.

20 Там же.

21 Там же. 
конвенция о постановке подводных, автоматически взрывающихся от соприкосновения мин 1907 г, которая запрещает ставить мины у берегов и портов противника с единственной целью прервать торговое мореплавание (ст. 2). Таким образом, можно утверждать, что правовая сторона морской блокады является предметом международных договоров и конвенций. Установление морской блокады правомерно только в случаях, прямо предусмотренных Уставом Организации Объединенных Наций (ООН). У тверждая принцип, согласно которому члены ООН обязаны воздерживаться от угрозы силой или ее применения (п. 4. ст. 2) 22, Устав ООН предоставляет право установления морской блокады Совету Безопасности, да и то лишь при определенных условиях:

во-первых, только Совет Безопасности «определяет существование любой угрозы миру, любого нарушения мира или акта агрессии» (ст. 39). Он делает соответствующие рекомендации или решает вопрос о мерах, необходимых для поддержания мира и безопасности;

во-вторых, эти меры первоначально не должны быть связаны с применением вооруженной силы (ст. 41);

в-третьих, если эти меры окажутся недостаточными, тогда Совет Безопасности может иметь право предпринимать действия вооруженными силами. «Такие действия, - устанавливает ст. 42 Устава ООН, могут включать демонстрации, блокаду и другие операции воздушных, морских и сухопутных сил Членов Организации» ${ }^{23}$.

Таким образом, в соответствии с Уставом ООН, признанным всеми членами Организации одним из важнейших источников современного международного права, морская блокада в случае угрозы миру может быть введена лишь Советом Безопасности. Г. Кельзен специально подчеркивает, что в соответствии с Уставом ООН, в отличие от Устава Лиги наций, подобные действия могут быть предприняты «лишь центральным органом - Советом Безопасности, и только после того, как Совет установит существование угрозы миру или нарушение мира».

Известно, что право государства на самооборону не затрагивается Уставом ООН и, разумеется, может включать право на установление блокады против агрессора. Однако, во-первых, речь здесь идет о блокаде, устанавливаемой в условиях отражения агрессии, т. е. в мирное время, и, во-вторых, Устав ООН предусматривает для этого строго определенное основание, такое как «если произойдет вооруженное

\footnotetext{
22 Устав Организации Объединенных Наций. URL: https://www.un.org/ru/charter-unitednations/index.html.

23 Там же.
} 
нападение на Члена Организации» (ст. 51) 24 . В октябре 1962 г. США, заявив о существующей якобы «угрозе со стороны Кубы», объявили об установлении блокады против берегов этой страны, тем самым открыто нарушили Устав ООН, так как:

во-первых, применили силу вопреки п. 3 ст. 2, который предписывает решать международные споры мирными средствами;

во-вторых, нарушили п. 4 ст. 2, отбросив возложенную на них как на Члена ООН обязанность воздерживаться от применения силы или угрозы силой против какого-либо государства, осуществили принудительные действия под предлогом самообороны вопреки ст. 51 Устава, которая допускает право на самооборону только при вооруженном нападении на Члена ООН, а Куба не совершала такого нападения;

в-третьих, предприняли принудительные действия под предлогом наличия угрозы миру, хотя определить существование угрозы миру может только Совет Безопасности (ст. 39), и только он вправе предпринимать принудительные действия, включая блокаду (ст. 42);

в-четвертых, нарушили ст. 53 Устава, так как согласно этой статье принудительные действия не могут предприниматься в силу региональных соглашений без полномочий, предоставленных Советом Безопасности, и тем самым поставили Совет Безопасности перед свершившимся фактом, нарушив суверенитет Кубы. Основным юридическим документом США при установлении блокады была Доктрина Монро. Но как сама Доктрина Монро, так и Межамериканский договор о взаимной помощи 1947 г. и Устав Организации американских государств, как утверждает В.А. Романов, не создают общепризнанной нормы международного права, более того, находятся в противоречии с ним и прежде всего с Уставом $\mathrm{OOH}^{25}$.

Государства при таком положении должны руководствоваться нормами Устава ООН, которые, будучи общепризнанными, имеют превалирующее значение по сравнению с нормами, которые содержатся в региональных соглашениях. Профессор Гронингенского университета Роллинг по этому поводу подчеркивает, что, если региональная норма нарушает международное право, она должна рассматриваться как запрещенная. При этом очень важно отметить, что профессор Роллинг ссылается на п. 5 ч. I Чапультепекского пакта от 8 марта 1945 г., который, по его мнению, должен быть признан несовместимым

\footnotetext{
24 Устав Организации Объединенных Наций. URL: https://www.un.org/ru/charter-unitednations/index.html.

25 Романов В.А. Исключение войны из жизни общества. Международно-правовые проблемы. Москва : Госюриздат, 1961. С. 89.
} 
с положением ст. 51 Устава ООН, так как дает возможность применения силы уже в случае лишь одной угрозы агрессии при отсутствии собственного вооруженного нападения. Вполне вероятно, что это в равной мере относится и к Уставу Организации американских государств и к Межамериканскому договору о взаимной помощи 1947 г., также незаконно поощряющий применение силы в отсутствии нападения.

Наряду с этим блокада Кубы противоречила принципу суверенности и ряду других принципов, принятых в самих региональных договорах и содержащихся, в частности, в ст. I Межамериканского договора о взаимной помощи 1947 г., ст. 1, 15, 16, 102 Устава Организации американских государств. Касаясь применения Доктрины Монро, юрист-международник того периода Ч. Хайд писал, что США не допускают мысли, что «какие-либо ограничения свободы действий других государств, которые могут проводиться на основании этой Доктрины, будут находиться в противоречии с теми или иными требованиями международного права» ${ }^{26}$.

В тот период США особо отмечали невозможность признания этой блокады, поскольку она проводилась Германией, Англией и Италией с использованием всех военных средств. Нельзя не вспомнить и высказывание другого государственного секретаря Лансинга по поводу «мирной» блокады Греции кораблями Атланты в 1916 г. Как пишет А.Л. Колодкин: «США не признают за иностранными государствами права на ущемление торговли незаинтересованных государств путем установления блокады при отсутствии состояния войны» ${ }^{27}$.

\section{ВЫВОДЫ}

Таким образом, возможность применения морской блокады и ее эффективность зависят от наличия определенных условий. Важнейшим из них является большая потребность блокируемой стороны в подвозе морем сырья для промышленности и продовольствия, т. е. наличия у нее развитой системы морских сообщений. Во время Первой и Второй мировых войн это были, в первую очередь, высокоразвитые в промышленном отношении островные государства Англия и Япония. Например, Англия перед Второй мировой ежегодно ввозила около 70 млн т различных грузов. Ее промышленность

\footnotetext{
26 Хайд Чарз Чини. Международное право, его понимание и применение Соединенными Штатами Америки / пер. с англ. И.С. Шохор ; под ред. В.Н. Дурденевского ; вступ. статья Л.А. Моджорян. Москва : Изд-во иностр. лит., 1950. Т. 1. С. 478.

27 Колодкин А.Л. Морская блокада и современное международное право. Советское государство и право. 1963. № 4. С. 101.
} 
полностью зависела от ввоза железной руды, меди, алюминия, нефти, хлопка и т. п. Продовольствие также почти полностью ввозилось морем из других стран. В Японии свыше $80 \%$ потребностей в сырье и полуфабрикатах обеспечивалось за счет внешней торговли. Захватив Маньчжурию и Центральный Китай, Японии удалось лишь снизить свою зависимость от ввоза, но не ликвидировать необходимость морских перевозок ${ }^{28}$. Такие государства, как Франция, США, Италия и Германия, хоть и в меньшей степени, чем островные, но тоже нуждались в доставке товаров морем из других стран.

Не менее важным условием для применения морской блокады является, кроме наличия у государства необходимых для этого сил и средств, географическое расположение государства. Серьезное влияние на возможность применения морской блокады оказывают и военно-географические условия воюющих стран, в т. ч. и наличие военно-морских воздушных баз, а также других опорных пунктов в районах, прилежащих к блокируемым. Например, в ходе Первой мировой войны само географическое положение Англии и баз ее флота облегчали ведение блокады Германии, в то время как географические особенности системы базирования немецкого флота затрудняли его действия по блокаде Англии. Во Второй мировой Германия, захватив территорию и базы на западе Франции и в Норвегии, создала себе определенные преимущества для блокадных действий, но реализовать их полностью не смогла.

Для эффективного осуществления морской блокады не менее важное значение имеет и система взглядов, господствующая во враждующих государствах, на способы ведения борьбы на море и в частности на морскую блокаду. Опыт подтверждает, что те страны, где к ней готовились еще в мирное время, добивались определенного эффекта и в ходе войны.

Рассмотрение истории зарождения и развития морской блокады и условий, в которых к ней прибегали воюющие стороны, в рамках данного исследования показывают, что она была мощным средством воздействия на экономический и военный потенциал врага, так как помогала изолировать его от внешнего мира. Изоляции флота враждующего государства от внешних связей через море, а также для обеспечения своих морских перевозок способствовала и борьба за запрещение выхода сил его флота из районов базирования, которая всегда

\footnotetext{
28 Лоченко Н.П., Шлома В.И. Морская блокада, как форма вооруженной борьбы. Морской сборник / гл ред. Г.И. Щедрин. Москва : Издательство «Красная звезда», 1971. № 2. С. 46. 
являлась специфическим видом морской блокады, хотя успешность ее после появления на арене борьбы подводных лодок, авиации и других сил и средств ведения войны резко снизилась.

Для достижения более полной изоляции флота противника и перерыва его внешних сообщений морская блокада часто усиливалась мерами политического, экономического, финансового и даже военного воздействия на нейтральные страны, через которые он мог получать необходимые материалы и информацию. Кроме того, во время Первой мировой войны, и особенно в ходе Второй, государства не ограничивались только блокадой неприятельского побережья. Они и в открытом море осуществляли жесткий контроль над торговлей нейтральных стран. Но, несмотря на все эти меры, морская блокада наиболее действенной становилась в том случае, если она подкреплялась сухопутной и воздушной блокадой, а также активными наступательными действиями против основных сил противника. История не дает ни одного примера, когда только блокадой даже стратегического масштаба достигались цели войны.

\section{АННОТАЦИЯ}

В статье исследуются правовая природа и особенности морской блокады в современном международном праве. Проводится краткое рассмотрение истории зарождения и развития морской блокады и условий, в которых к ней прибегали воюющие стороны. Выделяются обязательные (действенные) условия морской блокады. Анализируются международно-правовые основы объявления и оповещения морской блокады и обеспечения защиты интересов невоюющих государств. Установление морской блокады правомерно только в случаях, прямо предусмотренных Уставом ООН. Охарактеризована специфика мер политического, экономического, финансового и даже военного воздействия на нейтральные страны. Раскрыто содержание комплексной системы в форме общих правил, свода гарантий относительно специальной защиты культурных ценностей всех народов. Показано, что для применения морской блокады, кроме наличия у государства необходимых для этого сил и средств, важно и географическое расположение государства. Особое внимание уделяется статусу прибрежных вод как особого района и особо уязвимого морского района.

\section{ЛИТЕРАТУРА}

1. Колодкин А.Л. Морская блокада и современное международное право. Советское государство и право. 1963. № 4. С. 92-103. 
2. Лоченко Н.П., Шлома В.И. Морская блокада как форма вооруженной борьбы. Морской сборник / гл ред. Г.И. Щедрин. Москва : Издательство «Красная звезда», 1971. № 2. С. 41-47.

3. Морской энциклопедический словарь: в 3 т. Т. 2 / под ред. В.В. Дмитриева. Санкт-Петербург : Судостроение, 1993. 584 с.

4. Военно-морской словарь / гл. ред. В.Н. Чернавин. Москва : Воениздат, 1990. 511 с.

5. Парижский мирный договор 1856 г. URL: https://ru.wikisource.org/.

6. Лондонская декларация о праве морской войны 1909 г. URL: http://docs.cntd.ru/document/902038151.

7. Морской энциклопедический справочник : в 2 т. Т. 1 / под ред. Н.Н. Исанина. Ленинград : Судостроение, 1986. 503 с.

8. Конвенция о некоторых ограничениях в пользовании правом захвата в морской войне 1907 г. URL: http://hrlibrary.umn.edu/instree/ R1907j.html.

9. Гаагская конвенция о защите культурных ценностей в случае вооруженного конфликта 1954 г. URL: https://www.icrc.org/.

10. Устав Организации Объединенных Наций. URL: https://www.un.org/ $\mathrm{ru} /$ charter-united-nations/index.html.

11. Kelsen H. The Law of the United Nations. New York, 1951. 725 p.

12. Романов В.А. Исключение войны из жизни общества. Международно-правовые проблемы. Москва : Госюриздат, 1961. 200 с.

13. Хайд Чарз Чини. Международное право, его понимание и применение Соединенными Штатами Америки / пер. с англ. И.С. Шохор ; под ред. В.Н. Дурденевского ; вступ. статья Л.А. Моджорян. Москва : Изд-во иностр. лит., 1950. Т. 1. 478 с.

\section{Information about authors:}

Kostyria O. V.,

Candidate of Law Sciences, Associate Professor of Maritime Law Department National University "Odessa Maritime Academy"

8, Didrichson st. Odessa, Ukraine

Ivanova A. V.,

Candidate of Law Sciences, Associate Professor, Associate Professor of Maritime Law Department National University "Odessa Maritime Academy"

8, Didrichson st. Odessa, Ukraine

DOI https://doi.org/10.30525/978-9934-588-43-3/2.11 